Journal of Mathematics and Statistics Studies

ISSN: $2709-4200$

DOI: $10.32996 / j m s s$

Journal Homepage: www.al-kindipublisher.com/index.php/jmss

\title{
Statistical Analysis of the Factors Affecting Academic Achievement of Undergraduate Students: A Case Study of Faculty of Arts and Science Kufrah -Benghazi University
}

\author{
Muna H. Ali \\ Assistant Lecturer, Department of Mathematics, Faculty of Arts \& Science Kufrah, Benghazi University, Libya \\ $\square$ Corresponding Author: Muna H. Ali, E-mail: muna.alsnossi@uob.edu.ly
}

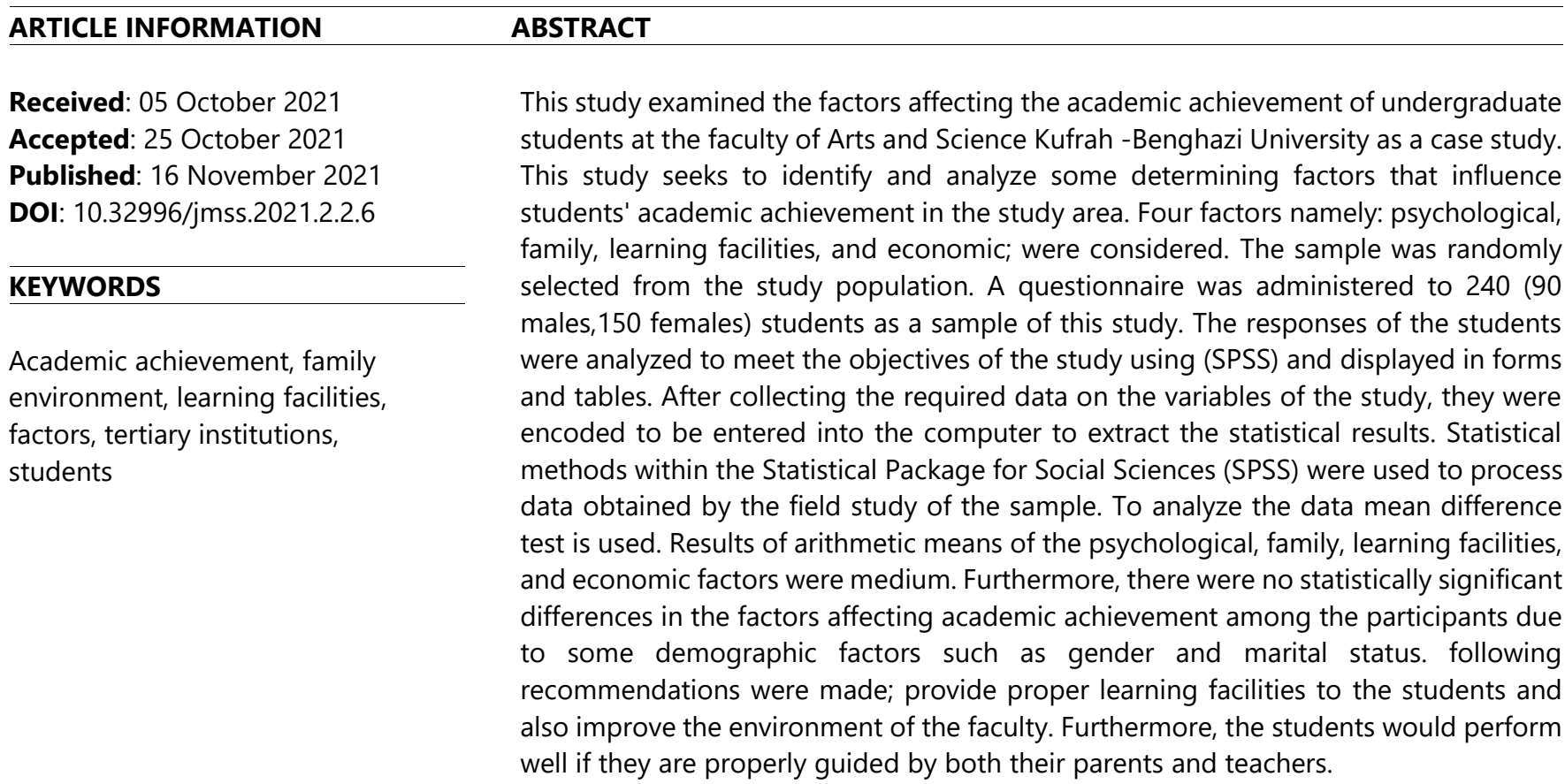

\section{Introduction}

Most undergraduate students take an introductory statistics course at some stage in their studies to fulfill the requirements of their degree programs. This is confirmed by Sachau et al. (1995) who highlighted that "most graduate programs require students to take statistics as a prerequisite. Most students in higher education institutions around the world have shown an aversion to statistics. At the University of South Africa, students who experience this dislike for statistics are in most cases enrolled in Social Sciences and Behavioural Sciences majors. Most students go to university with different experiences and backgrounds in statistics, as this subject is not fully taught in the surrounding high schools and high schools. Rather, school-level math literacy is taught as a replacement for pure maths to some students, especially those who have less passion for math. This may be one of the reasons that lead to different attitudes towards statistics or any related course".

"Several colleges at the university, especially those offering technical programs, admit students who have a minimum of four as an Admission Point Score (APS) in mathematics. A minimum score of twenty-six APS is required from students to be admitted to the core programs, which generally take a minimum of four years to complete. A very limited number of students are required to score in pure mathematics and many of them are placed in the basic phase that is used in the form of preparation for first grade. Despite this process, achievement rates in the statistics course do not improve and result in several students having to repeat statistics at their freshman levels before they are allowed to continue their studies. This has been found to be one of the threats

Copyright: (c) 2021 the Author(s). This article is an open access article distributed under the terms and conditions of the Creative Commons Attribution (CC-BY) 4.0 license (https://creativecommons.org/licenses/by/4.0/). Published by Al-Kindi Centre for Research and Development, London, United Kingdom. 
to students completing their degrees in record time", as also reported by Onwuegbuzie, et al. (1997). "Poor performance in statistics is often preceded by negative perception", as highlighted by Galli et al. (2008).

This study investigates the factors affecting the academic achievement of undergraduate students enrolled in statistics at the University of Benghazi. Statistics modules are offered by a faculty that attracts students with different backgrounds and competencies in statistics and mathematics. Although some of these students excelled in high school or pre-college studies, it is troubling to note their dismal performance in statistics or statistics-related courses at the college level. The poor performance of students in first-year undergraduate statistics.

\subsection{Statement of the Problem}

The most widespread argument is that the socioeconomic status of students affects the quality of their academic performance. Measuring the academic performance of students has been a challenging subject in social, educational, psychological, environmental, and personal factors. The usefulness of these studies lies in the need to undertake corrective measures that improve the academic performance of graduate students. Among all the factors, socioeconomic status is one of the most researched and debated factors among education professionals who contribute towards the academic performance of students. These factors strongly influence academic search, although they vary from person to person. This study, therefore, aims to identify and analyze some determining factors of academic achievement in higher education institutions. Therefore, this study will consider the psychological, family, learning facilities, and economic as factors that determine the academic achievement of students.

\subsection{Objective of the Study}

This study aims to identify and analyze some determining factors of academic achievement at the Faculty of Arts and Science Kufra -Benghazi University.

\subsection{Research Questions}

This study was guided by the following questions;

1. What are the important factors that affect the academic achievement of undergraduate students at the faculty of Arts and Science Kufra -Benghazi University?

2. What are the failure factors that retard the academic achievement of undergraduate students at the faculty of Arts and Science Kufra -Benghazi University?

\section{Literature Review}

As it is known that the key to success for any nation lies in their concern and development of the education sector. As education is promoted in the nation, this reduces the illiteracy rate that ultimately reduces unemployment, which is one of the biggest curses on any nation (Ahmad, Arshad, \& Ahmad, 1991). Education is the main component of preparing qualified human cadres that keep up with contemporary global changes. In addition, it plays a great role in the development and control of the whole system to meet the needs and desires of the society, and provide and satisfy the increasing requirements. The social, psychological, and family factors that face students in society, environment, and home cause low achievement. These causes motivate universities to investigate the causes of students' low achievement and to endeavor to find a radical solution to handle the problem using planned and professional educational methods because of their great effect on students (Baslanti, 2008).

Many studies discuss students' problems in universities around the world. An academic paper written by Dixon and Kurpius (2008), examines the relationship between depression and stress with self-esteem and mattering for college students by taking a survey of a number of university students. It was concluded that self-esteem and mattering increase the ability of stress to predict depression and as a result will affect students' learning. Bataina (2014) aimed to investigate the factors causing low academic achievement in Educational Psychology among the students of the College of Education, King Saud University from the perspective of students and faculty members. It applied the descriptive and analytical method to a sample of (140) students. It concluded that the weak motivation to study was the key cause of low academic achievement from the perspective of the faculty member. Also, clear and fair course policies communicated to students in effective ways also help further student learning (Nolen, 2003). CanalesGonzales and Kranz (2008) from the University of Texas-Pan American discussed the stress received by the pharmacy curriculum in 2008. A pilot study was carried out to find out the level of stress faced by the student in the Cooperative Pharmacy Program, the reasons, and the way to reduce it. Interviews were conducted with 17 students. During the interview, each student must answer two questionnaires. The first questionnaire has seven demographic items and the second questionnaire has 13 qualitative items. Descriptive Statistics were examined. It was found that the students face average to above-average levels of stress with a mean of 3.8 out of $5.88 \%$ of the students said that the level of stress increases as they move from the first semester to the second semester and so on. Amitava Raychaudhuri, et. al., (July 2010), found that numerous studies have been done to identify those factors which are affecting students' academic performance. The student's academic performance depends on a number of socio-economic 
factors like students' attendance in the class, family income, mother's and father's education, the teacher-student ratio, presence of trained teachers in school, sex of the student, and distance of schools. Tamweaknesses2) conducted a study about weakness in students' academic performance. In this study, he pointed out this problem has become a global problem. He found that the number of pupils at Al Salmiat Primary School suffer from this problem; therefore, he searched for solutions to this problem.

The researcher also explained the factors that lead to poor academic achievements, such as social factors, economic factors, and political conditions. The study recommended staying away from violence and inappropriate words with students who suffer from academic weakness and encouraging these students by offering them some gifts and paying them more attention. The other factor that affects student learning outcomes is the family environment. Sutarti (2016) shows that the family environment has a positive and significant impact on students' learning outcomes. The family environment gives the first influence in the formation of one's personality. The family is where the first learning process takes place; thus, it is expected to instigate good learning habits. However, the family environment can negatively impact learning performance when there is a lack of support on study habits and discipline in it. Family environment, especially parents, plays a big role because they are directly related to children. Parents have a big influence on students' learning success. According to Indrakusuma and Daien (2003), the high level of parental education, the size of parents' income, the familiarity of parents' relationship with children affect students' learning success.

Almuammria (2015) performed a study about the impact of the environment in enhancing the academic achievement of students. The researcher tried to focus on the secondary level because it is in the middle of studying years and consider the age of adolescence, associated with behaviors that some teachers may overlook; consequently, this requires the presence of a specialist or social worker. The researcher showed that there is a range of factors affecting academic achievement such as; learner factors, family factors, and school factors. The study recommended the need for direct contact between the parents and the school and the participation of parents in providing feedback and support for the school. On the other hand, the role of the school is to inform the parents about their children's behavior within the school as well as the participation of parents of students in religious, national, and cultural events. The study also recommended the need to consider the family and the school as one unit that is a compliment for each other and this integration and cooperation help to achieve the educational and the scientific goals. According to Slameto (2010), learning facilities factors that affect learning include teaching method, curriculum, building conditions. According to Ahmadi (2007), a good school environment is a challenging environment that stimulates students to learn, provides a sense of security and satisfaction, and supports them to achieve the expected goals. learning buildings is one of the learning facilities that influence the academic performance of students. The designs of the classroom and its lighting also determine if students will perform well or not. Dunn (1985) said that students perform well than in a dark. Without light, it is obvious that students may develop bad sight. Also, Karemera (2003) found that students' performance is significantly correlated with satisfaction with the academic environment and the facilities of library, computer lab and etc.

Beblo and Lauer (2004), analyzed the relationship between economic change and educational achievement and addressed the financial resources such as parents'" wealth or income were very slightly related to the educational achievement of their children. Having a job also influences the academic achievement of students in a negative way. A study of Tamaoka, Ninomiya, and Nakaya (2003) showed that part-time work hurts students' satisfaction with university life and this might be because the work reduces time to concentrate on their study or research.

\section{Methodology}

The present study investigated the factors affecting the academic achievement of undergraduate students at the faculty of Arts and Science Kufrah -Benghazi University. The sample was randomly selected from the study population. A questionnaire was administered on 240 (90 males, 150 females) samples. The responses of the students were analyzed to meet the objectives of the study using (SPSS) and displayed in forms and tables. After collecting the required data on the variables of the study, they were encoded to be entered into the computer to extract the statistical results. Statistical methods within the Statistical Package for Social Sciences (SPSS) were used to process data obtained by the field study of the sample. The first part is related to basic (demographic) information, such as gender, grade, marital status. The second part comprised four fields; A. psychological factors of (9) paragraphs (1-5). B. family factors of (7) paragraphs (6-11). C. learning facilities factors of (7) (12-18) paragraphs. D. economic factors of (9) paragraphs (19-25). The extent of existence for all variables in the research area was measured on a five-point Likert scale ranging from strongly agree (5) marks, agree (4) marks, neutral (3) marks, disagree (2) marks, and strongly disagree (1) mark. It will be low level if the arithmetic means ranged $(1-2.33)$ and that means it causes low academic achievement, medium level if the arithmetic means ranged (2.34-3.67) because it is not the most significant one causes of low academic achievement, high level if the arithmetic means ranged (3.68 - 5) and that means it does not greatly cause low academic achievement.

The author used the following statistical methods: 
- Cronbach Alpha Test to test reliance on the tool used to collect data in measuring the study's variables.

- Frequencies to identify the distribution of the sample on the demographic variables.

- Descriptive statistics: arithmetic mean, frequencies, and percentages to describe the opinions of the recipients on the variables to define the importance of the questionnaire's phrases.

- (T-Test) to hold a dual comparison in testing the questions of the study to verify the statistical significance of results obtained and determining differences to be attributed to dual variables. ANOVA test to test the statistically significant differences of the study's demographic variables.

- Scheffé's test to find post-differences if existed in ANOVA test

\section{Results and Discussion}

Characteristics of the sample can be classified in the following table

Table (1) Characteristics of the sample

\begin{tabular}{|llll|}
\hline Variable & category & Frequency & Percent \\
\hline Gender & Male & 90 & 37.5 \\
\cline { 2 - 4 } & Female & 150 & 62.5 \\
\cline { 2 - 4 } & Total & 240 & 100.0 \\
\hline \multirow{5}{*}{ Garital status } & Married & 52 & 21.7 \\
\cline { 2 - 4 } & Single & 162 & 67.5 \\
\cline { 2 - 4 } & Widowed & 10 & 4.2 \\
\cline { 2 - 4 } & Divorced & 16 & 6.7 \\
\cline { 2 - 4 } & Total & 240 & 100.0 \\
\hline Family income & high distinction & 8 & 3.3 \\
\cline { 2 - 4 } & Distinction & 18 & 7.5 \\
\cline { 2 - 4 } & Credit & 54 & 22.5 \\
\cline { 2 - 4 } & Pass & 160 & 66.7 \\
\cline { 2 - 4 } & Total & 240 & 100.0 \\
\cline { 2 - 4 } & Medium & 47 & 19.6 \\
\cline { 2 - 4 } & Low & 53 & 100.0 \\
\hline & Total & 240 & \\
\hline
\end{tabular}

Table (1) illustrates that females rated (62.5\%) and males rated (37.5\%). It also illustrates that the marital status of married, single, widowed, and divorced students rated (21.7, 67.5, 4.2, and 6.7, respectively). Furthermore, grades of academic performance of BUK students - referred to the end results in the previous academic year- of high distinction, distinction, credit, and pass rated (3.3, 7.5, 22.5, and 66.7, respectively). Also illustrates family income of high, medium, and low rated (19.6, 58.3, 22.1, respectively).

To test the questionnaire's reliability to measure the internal consistency between items in a scale, Cronbach's alpha is used and should to make sure that not to mix positively and negatively worded questions otherwise Alpha will be negative. Also, should do it for each scale, not for the entire questionnaire of the study.

Table (2) Reliability of total items

\begin{tabular}{|ll|}
\hline Cronbach Alpha & No of items \\
\hline 0.722 & 4 \\
\hline
\end{tabular}

Table (3) Reliability of individual items.

\begin{tabular}{|lll|}
\hline Field & Cronbach Alpha & No of items \\
\hline Psychological factors & 0.859 & 9 \\
\hline Family factors & 0.650 & 7 \\
\hline Learning facilities & 0.611 & 7 \\
\hline Economic factors & 0.753 & 9 \\
\hline
\end{tabular}


Table 3 shows that there were cohesion, coherence, and consistency among the paragraphs. According to Keith S. Taber (2017), alpha values were described as the high coefficient was $(0.859)$ and the lowest one was $(0.611)$. This reports the stability of the results of applying the questionnaire. Values of this coefficient (Alpha $>0.60$ ) are appropriate to applying the questionnaire to the study. To answer the first objective of the study to determine the important factors that affect students' academic performance, the arithmetic means and standard deviations of the factors causing low academic achievement among faculty of Arts and Science Benghazi University students, in general, and those of each field in the questionnaire was estimated (as shown in table 4).

Table (4): Arithmetic means, standard deviations, and ranks of the factors causing low academic achievement among faculty of Arts and Science Benghazi University students.

\begin{tabular}{|lllll|}
\hline Field & Means & \multicolumn{2}{l|}{ Standard deviation Rank } & Significance \\
\hline Psychological factors & 3.415 & 0.504 & 1 & Medium \\
\hline Economic factors & 3.327 & 0.489 & 2 & Medium \\
\hline Family factors & 3.263 & 0.431 & 3 & Medium \\
\hline Learning facilities & 3.192 & 0.530 & 4 & Medium \\
\hline Total & 3.314 & 0.476 & & \\
\hline
\end{tabular}

The previous table illustrates that factors causing low academic achievement among faculty of Arts and Science Benghazi University students were medium, with an arithmetic mean of (3.314) and a standard deviation of (0.476). All sections were medium, with arithmetic means of (3.192- 3.415). " psychological factors " were ranked first, with an arithmetic mean of (3.415) and a standard deviation of (0.504). It was followed, in the second rank, by "Economic factors ", with an arithmetic mean of (3.327) and a standard deviation of (0.489). "Family factors" was ranked third, with an arithmetic mean of (3.263) and a standard deviation of (0.431). "Learning factors" was ranked last, with an arithmetic mean of (3.192) and a standard deviation of (0.530). Results of the paragraphs of each field were, as follows:

\subsection{Psychological factors}

Arithmetic means standard deviations and ranks of the psychological factors were estimated, as shown in table (5).

Table (5): Arithmetic means standard deviations and ranks of the psychological factors.

\begin{tabular}{|l|l|l|l|l|l|}
\hline NO & Paragraph & Means & Standard deviation & Rank & Significance \\
\hline 5 & Low academic subjects' interest & 3.8750 & 0.67919 & 1 & High \\
\hline 2 & $\begin{array}{l}\text { Unfeeling of being a part of the 3.8542 } \\
\text { campus community }\end{array}$ & 0.62679 & 2 & High \\
\hline 4 & $\begin{array}{l}\text { Absence of trained teachers at the 3.8042 } \\
\text { university }\end{array}$ & 0.61974 & 3 & High \\
\hline 1 & $\begin{array}{l}\text { not being able to stop or control } 3.7667 \\
\text { worrying }\end{array}$ & 0.64986 & 4 & High \\
\hline 9 & $\begin{array}{l}\text { students' attendance in the class } \\
\text { Low self-confidence }\end{array}$ & 3.6375 & 0.97984 & 5 & Medium \\
\hline 7 & $\begin{array}{l}\text { Weak adaptation between students } 2.9042 \\
\text { and faculty members. }\end{array}$ & 1.06444 & 6 & Medium \\
\hline 8 & $\begin{array}{l}\text { The shyness of asking questions on 2.7417 } \\
\text { academic subjects. }\end{array}$ & 1.03896 & 7 & Medium \\
\hline 6 & $\begin{array}{l}\text { Courses do not match students'2.6542 } \\
\text { mental abilities. }\end{array}$ & 1.03958 & 9 & Medium \\
\hline Total & 3.415 & 0.504 & Medium \\
\hline
\end{tabular}

Table (5) illustrates that the psychological factors were medium, with an arithmetic mean of (3.415) and a standard deviation of (0.504). The phrases of the section were high and medium, with arithmetic means of (2.654- 3.875). " Low academic subjects' interest " was ranked first, with an arithmetic mean of (3.875) and a standard deviation of (0.67919), with a high degree. "Courses do not match students' mental abilities " was ranked last, with an arithmetic mean of (2.654) and a standard deviation of (1.04), with a medium degree.

\subsection{Family factors}

Arithmetic means standard deviations and ranks of the family factors were estimated, as shown in table (6). 
Table (6): Arithmetic means standard deviations and ranks of the family factors.

\begin{tabular}{|c|c|c|c|c|c|}
\hline NO & Paragraph & Means & Standard deviation & Rank & Significance \\
\hline 7 & $\begin{array}{l}\text { Low level of following- up and control } \\
\text { by the family. }\end{array}$ & 3.5542 & 1.03757 & 1 & Medium \\
\hline 3 & Parents' separation & 3.5458 & 0.94514 & 2 & Medium \\
\hline 5 & $\begin{array}{l}\text { Students' families are outside the city } \\
\text { of the university }\end{array}$ & 3.5208 & 1.05477 & 3 & Medium \\
\hline 4 & $\begin{array}{l}\text { Family compares their children with } \\
\text { peers. }\end{array}$ & 3.4750 & 1.01835 & 4 & Medium \\
\hline 2 & Inappropriate family environment & 3.4500 & 1.00916 & 5 & Medium \\
\hline 1 & Parents disappointed for done by me & 2.8042 & 1.03049 & 6 & Medium \\
\hline 6 & $\begin{array}{l}\text { Unfeeling stability and calmness at } \\
\text { home. }\end{array}$ & 2.4917 & 0.89626 & 7 & Medium \\
\hline Total & & 3.263 & 0.431 & \multicolumn{2}{|c|}{ Medium } \\
\hline
\end{tabular}

Table (6) illustrates that the family factors were medium, with an arithmetic mean of (3.263) and a standard deviation of (0.431). The phrases of the section were medium, with arithmetic means of (2.492- 3.554). " Low level of following- up and control by the family" was ranked first, with an arithmetic mean of (3.554) and a standard deviation of (1.0375), with a medium degree. " Unfeeling of stability and calmness at home" was ranked last, with an arithmetic mean of (2.492) and a standard deviation of (0.896), with a medium degree.

\subsection{Learning facilities}

Arithmetic means standard deviations and ranks of the learning facilities factors were estimated, as shown in table (7).

Table (7): Arithmetic means standard deviations and ranks of the learning facilities factors.

\begin{tabular}{|c|c|c|c|c|c|}
\hline NO & Paragraph & Means & Standard deviation & Rank & Significance \\
\hline 1 & $\begin{array}{l}\text { Bad conditions of university buildings } \\
\text { negatively influence academic } \\
\text { performance }\end{array}$ & 3.5625 & 1.00431 & 1 & Medium \\
\hline 5 & $\begin{array}{l}\text { Cyber cheating because of using } \\
\text { technology tools }\end{array}$ & 3.5333 & 0.92780 & 2 & Medium \\
\hline 7 & $\begin{array}{l}\text { The ratio between room area to the } \\
\text { number of students is not suitable }\end{array}$ & 3.4958 & 0.97671 & 3 & Medium \\
\hline 6 & Unavailability of e-learning system & 3.4625 & 0.93662 & 4 & Medium \\
\hline 4 & $\begin{array}{l}\text { Lack of assistance tools so cannot be } \\
\text { reached to all the students }\end{array}$ & 3.4500 & 0.97543 & 5 & Medium \\
\hline 3 & $\begin{array}{l}\text { Inappropriate university climate and } \\
\text { technology }\end{array}$ & 2.4667 & 0.88628 & 6 & Medium \\
\hline 2 & $\begin{array}{l}\text { Unavailability of a library to provide } \\
\text { books and scientific references }\end{array}$ & 2.3750 & 0.88750 & 7 & Medium \\
\hline Total & & 3.192 & 0.530 & \multicolumn{2}{|c|}{ Medium } \\
\hline
\end{tabular}

Table (7) illustrates that the learning facilities factors were medium, with an arithmetic mean of (3.192) and a standard deviation of (0.530). The phrases of the section were medium, with arithmetic means of (2.375-3.563). "Bad conditions of university buildings negatively influence academic performance" was ranked first, with an arithmetic mean of (3.375) and a standard deviation of (1.0043), with a medium degree. " Unavailability of a library to provide books and scientific references" was ranked last, with an arithmetic mean of (2.375) and a standard deviation of (0.8875), with a medium degree. 


\subsection{Economic factors}

Arithmetic means standard deviations and ranks of the economic factors were estimated, as shown in table (8).

Table (8): Arithmetic means standard deviations and ranks of the economic factors.

\begin{tabular}{|c|c|c|c|c|c|}
\hline NO & Paragraph & Means & Standard deviation & Rank & Significance \\
\hline 8 & $\begin{array}{l}\text { Not having internet access so can } \\
\text { support the study. }\end{array}$ & 3.6792 & 0.94248 & 1 & Medium \\
\hline 5 & $\begin{array}{l}\text { High transportation fees to the } \\
\text { university. }\end{array}$ & 3.6417 & 0.97066 & 2 & Medium \\
\hline 6 & $\begin{array}{l}\text { Absence of financial incentives to } \\
\text { support academic achievement }\end{array}$ & 3.6208 & 0.95176 & $\beta$ & Medium \\
\hline 4 & $\begin{array}{l}\text { Wealth makes the student feel that } \\
\text { studying is unimportant. }\end{array}$ & $\mathrm{t} 3.5750$ & 0.98238 & 4 & Medium \\
\hline 2 & The high cost of books and stationery. & 3.5375 & 0.99299 & 5 & Medium \\
\hline 3 & Low pocket money & 3.4833 & 1.00195 & 6 & Medium \\
\hline 9 & $\begin{array}{l}\text { Students' feelings of inferiority } \\
\text { compared to other peers with good } \\
\text { economic conditions. }\end{array}$ & 3.4542 & 1.00104 & 7 & Medium \\
\hline 7 & The high number of family members & 2.4958 & 0.91018 & 8 & Medium \\
\hline 1 & $\begin{array}{l}\text { Students' work affects their time to } \\
\text { study }\end{array}$ & 2.4542 & 0.88098 & 9 & Medium \\
\hline Tota & & 3.327 & 0.489 & \multicolumn{2}{|c|}{ Medium } \\
\hline
\end{tabular}

Table (8) illustrates that the economic factors were medium, with an arithmetic mean of (3.327) and a standard deviation of (0.489). The phrases of the section were medium, with arithmetic means of (2.454- 3.679). " Not have an internet access so can support the study" was ranked first, with an arithmetic mean of (3.679) and a standard deviation of (0.9425), with a medium degree. " Students' work affects their time to study" was ranked last, with an arithmetic mean of (2.454) and a standard deviation of (0.881), with a medium degree.

Now for the second objective of this study is to determine if the factors that cause low academic achievement among faculty of Arts and Science Benghazi University students are significant differences due to gender, marital status at the level of ( $\alpha \leq 0.05)$.

For gender: to answer this question, $(\mathrm{T})$ value of the scores' means of the factors causing low academic achievement among faculty of Arts and Science Benghazi University students, according to gender (female-male), as follows:

Table (9): Arithmetic means, standard deviations, and (T) value of male and female participants' responses

\begin{tabular}{|l|l|l|l|l|}
\hline \multirow{2}{*}{ Domain } & Group & $\begin{array}{l}\text { Arithmetic } \\
\text { mean }\end{array}$ & (T) Value & Level Significance \\
\hline $\begin{array}{l}\text { Psychological } \\
\text { factors }\end{array}$ & Males & 3.4167 & 1.724 & 0.334 \\
\cline { 2 - 3 } & Females & 3.3367 & & \\
\hline Family factors & Males & 3.1810 & -2.371 & 0.538 \\
\cline { 2 - 3 } & Females & 3.3124 & & \\
\hline Facilities factors & Males & 3.2222 & 0.944 & 0.017 \\
\cline { 2 - 3 } & Females & 3.1743 & & \\
\hline Economic factors & Males & 3.3667 & 1.597 & 0.145 \\
\cline { 2 - 3 } & Females & 3.3030 & & \\
\hline
\end{tabular}

Table (9) illustrates that there are no statistically significant differences at the level of $(\alpha \leq 0.05)$ between the arithmetic means of the two groups (i.e. males and females) participants' responses in all fields. It was more than (0.05) which is statistically insignificant, except for (facilities factors), in favor of males because their arithmetic mean was higher than that of females.

For marital status: to answer this question, (ANOVA) was used in studying the means of the factors causing low academic achievement among faculty of Arts and Science Benghazi University students according to their marital status, as shown in table (10) 
Table (10): ANOVA analysis of the means of the factors causing low academic achievement among faculty of Arts and Science Benghazi University students according to their marital status

\begin{tabular}{|c|c|c|c|c|c|c|}
\hline Domain & $\begin{array}{l}\text { Source } \\
\text { variance }\end{array}$ & $\begin{array}{l}\text { fum } \\
\text { squares }\end{array}$ & $\begin{array}{l}\text { of degree } \\
\text { freedom }\end{array}$ & $\begin{array}{l}\text { Mean } \\
\text { square }\end{array}$ & (F) Value & $\begin{array}{l}\text { Level } \\
\text { Significance }\end{array}$ \\
\hline \multirow{3}{*}{$\begin{array}{l}\text { Psychological } \\
\text { factors }\end{array}$} & Between Groups & 1.524 & 3 & 0.508 & \multirow[t]{3}{*}{4.333} & \multirow[t]{3}{*}{0.005} \\
\hline & Within Groups & 27.678 & 236 & 0.117 & & \\
\hline & Total & 29.202 & 239 & & & \\
\hline \multirow[t]{3}{*}{ Family factors } & Between Groups & 1.701 & 3 & 0.567 & \multirow[t]{3}{*}{3.311} & \multirow[t]{3}{*}{0.021} \\
\hline & Within Groups & 40.421 & 236 & 0.171 & & \\
\hline & Total & 42.122 & 239 & & & \\
\hline \multirow[t]{3}{*}{ Facilities factors } & s Between Groups & 0.213 & 3 & 0.071 & \multirow[t]{3}{*}{0.487} & \multirow[t]{3}{*}{0.691} \\
\hline & Within Groups & 34.446 & 236 & 0.146 & & \\
\hline & Total & 34.659 & 239 & & & \\
\hline \multirow{3}{*}{$\begin{array}{l}\text { Economic } \\
\text { factors }\end{array}$} & Between Groups & 0.183 & 3 & 0.061 & \multirow[t]{3}{*}{0.674} & \multirow[t]{3}{*}{0.568} \\
\hline & Within Groups & 21.338 & 236 & 0.090 & & \\
\hline & Total & 21.521 & 239 & & & \\
\hline
\end{tabular}

Table (10) indicates that there are no statistically significant differences at the level of $(\alpha \leq 0.05)$ on the means of the factors of facilities factors and economic factors causing low academic achievement among faculty of Arts and Science Benghazi University students according to their marital status. However, it seems statistically significant for the psychological and family factors where they were lower than (0.05). Thus, Scheffe' Test of post-test comparisons was conducted, as shown in table (11).

Table (11): Post-comparisons using Scheffe's method in studying the means of the factors causing low academic achievement among faculty of Arts and Science Benghazi University students according to their marital status.

\begin{tabular}{|l|l|l|l|l|l|l|}
\hline Domain & Group & Means & married & single & widowed & divorced \\
\hline \multirow{2}{*}{$\begin{array}{l}\text { Psychological } \\
\text { factors }\end{array}$} & married & 3.2236 & & & & \\
\cline { 2 - 8 } & single & 3.3966 & $0.17305^{*}$ & & & \\
\cline { 2 - 8 } & widowed & 3.5250 & 0.30144 & 0.12840 & & \\
\cline { 2 - 8 } & divorced & 3.4297 & 0.20613 & 0.03308 & 0.09531 & \\
\hline Family factors & married & 3.1044 & & & & \\
\cline { 2 - 8 } & single & 3.2714 & $0.20160^{\star}$ & & & \\
\cline { 2 - 8 } & widowed & 3.3060 & 0.16703 & 0.03457 & & \\
\cline { 2 - 8 } & divorced & 3.3393 & 0.23489 & 0.03329 & 0.06786 & \\
\hline
\end{tabular}

Table (11) illustrates that there are differences between the intersected categories according to marital status. Hence, arithmetic means are scrutinized to define the category with the highest one; i.e. to which differences tend. Here, they were those of single in psychological and family factors.

\section{Discussion}

Factors affecting academic achievement:

\subsection{Psychological factors:}

Results of arithmetic means of the psychological factors were medium. " Low academic subjects' interest " was ranked first with a high degree because it is not the most significant cause of low academic achievement. It seems that students can communicate well with university members and they think that teachers are well trained and can control their subjects. Also being worried is not the most significant cause of low academic achievement. " Courses do not match students' mental abilities " was ranked last because the students believe that such courses that do not match students' mental abilities cause low academic achievement. Accordingly, they feel shy of asking questions related to courses with low self-confidence. Hence, their academic achievement becomes low. This agrees with Dixon and Kurpius (2008), illustrating that self-esteem and mattering decrease the ability to get good learning outcomes. The results also support earlier findings showing that clear and fair course policies communicated to students in effective ways also help further student learning (Nolen, 2003). 


\subsection{Family factors:}

Results of arithmetic means of the family factors were medium. "Low level of following- up and control by the family" was ranked first with a medium degree because it is not the most significant family cause of low academic achievement. "Unfeeling of stability and calmness at home" was ranked last, with a medium degree because it causes low academic achievement. Accordingly, an inappropriate family environment and weak encouragement to learn can lead to low academic achievement. This agrees with Sutarti (2016) who states that the family environment can negatively impact learning performance when there is a lack of support on study habits and discipline in it.

\subsection{Learning facilities factors:}

Results of arithmetic means of the learning facilities factors were medium. " Bad conditions of university buildings negatively influence academic performance " was ranked first with a medium degree because it does not greatly cause low academic achievement as they are available. " Unavailability of a library to provide books and scientific references " was ranked last, with a medium degree because students need an appropriate place and environment to search, study and find information about their subjects. According to Slameto (2010) and Ahmadi (2007), a good school environment is a challenging environment that stimulates students to learn. Also, Karemera (2003) found that students' performance is significantly correlated with satisfaction with the academic environment and the facilities of library, computer lab and etc.

\subsection{Economic factors:}

Results of arithmetic means of the economic factors were medium. " Not having an internet access so can support the study " was ranked first with a medium degree because it does not greatly cause low academic achievement. "Students' work affects their time to study " was ranked last, with a medium degree because the work affects the time for students to focus on their assignments, causing low academic achievement. This agrees with a study by Tamaoka, Ninomiya, and Nakaya (2003) showed that part-time work hurts students' satisfaction with university life and this might be because the work reduces time to concentrate on their study or research.

To answer the second question: are there statistically significant differences in the factors causing low academic achievement among faculty of Arts and Science Benghazi University students due to gender, marital status at the level of ( $\alpha \leq 0.05)$ ?

\subsection{Gender:}

There are no statistically significant differences in the factors causing low academic achievement among faculty of Arts and Science Benghazi University students due to gender. It was more than (0.05) which is statistically insignificant, except for (facilities factors), in favor of males because their arithmetic mean was higher than that of females. This is because girls may stay more at the university so that they have a different attitude about their opinion on learning facilities.

\subsection{Marital status:}

There are no statistically significant differences at the level of $(\alpha \leq 0.05)$ on the means of the factors of facilities factors and economic factors causing low academic achievement among faculty of Arts and Science Benghazi University students according to their marital status. However, they are statistically significant for the psychological and family factors where they were lower than (0.05). They were those single in psychological and family factors.

\section{Conclusion}

This study has donated to the literature on perceived factors that affect the academic achievement of students at faculty of Arts and Science Kufra -Benghazi University by investigating the effect of student-related factors such as; psychological, family, learning facilities and economic The study has revealed through its perceived findings that from the results of arithmetic means of the psychological, family, learning facilities and economic factors were medium. Furthermore, there were no statistically significant differences in the factors causing low academic achievement among the participants due to some demographic factors such as gender and marital status. Results of this study have inferences for educational policy in Benghazi University, parents, and teachers.

\subsection{Recommendations}

Based on the results mentioned above, the author recommends the following:

1. The university leadership in Libya should intensify efforts to provide effective learning materials and develop teaching methods to improve the academic achievement of students. In addition, the appropriate class size must be maintained to promote academic achievement.

2. The university leadership in Libya should provide the students free lessons and workshops in the university to improve their achievement. 
3. Parents /guardians should always support and inspire their districts by equipping them with the quality of materials necessary to excel in their academic pursuits.

4. The Libyan government should vigorously enforce the law prohibiting the existence of cult organizations to eradicate cultism among students of Libyan universities.

5. The Libyan government should further inspire the expansion of existing universities by establishing more technologybased universities to address the problem of unmet social demand for higher education and technological advancement in Libya.

\subsection{Future Research and Limitations}

The present study has limitations. Future research should raise the sample size and collect responses from various universities. Future research could apply a research method, such as in-depth interviews to draw feelings. In this sense, it is recommended to implement quantitative and qualitative methods in future studies to make it possible to acquire both results. Finally, although this study concentrates on the factors affecting academic achievement, future studies could investigate other topics such as emotional psychological status instead of achievement.

\section{References}

[1] Ahmad, E., Arshad, M. F., \& Ahmad, A. (1991). Learning and earning profiles in Pakistan's informal sector. Pakistan Economic and Social Review, 29(2), 77-98.

[2] Ahmadi, A. (2007). Psikologi Sosial. Jakarta: PT. Rineka Cipta.

[3] Almuammria, M. (2015). The impact of the environment in enhancing the academic achievement of students. Scientific Library, Beirut 13.

[4] Baslanti, U. (2008). Investigating the underachievement of university students in Turkey: Exploring subscales. International journal of progressive education, 4(2): 1 - 29.

[5] Bataina, M. (2014). Factors causing low academic achievement in Educational Psychology among College of Education, King Saud University from the perspective of students and faculty members: A research study. Kingdom of Saudi Arabia: King Saud University.

[6] Beblo, M., \& Lauer, C. (2004). Do family resources matter? Educational attainment during the transition in Poland. Economics of Transition, 12(3), 537-558.

[7] Canales-Ganzales, L, P, \& Kranz, P, L (2008), Perceived stress by students in a pharmacy curriculum, EDU, 129(1), $139-146$.

[8] Dixon, S. \& Kurpius, S. (2008). Depression and college stress among university undergraduates: Do mattering and self-esteem make difference? Journal of college student development, 49(5), 412-424.

[9] Dunn, R. (1985). Light up their lives. Research on the effect of lighting on children's achievement and behavior. The reading teacher, 38(19). 863-869.

[10] Galli, S., Chiesi, F., and Primi, C. (2008), The construction of a scale to measure mathematical ability in psychology students: an application of the Rasch model: Testing Psicometria Metodologia, TPM, Vol.15, 1-16.

[11] Indrakusuma \& Daien, A. (2003). Pengantar Ilmu Kependidikan. Surabaya: Usaha Nasional.

[12] Karemera, D. 2003. The Effects of the academic environment and background characteristics on students' satisfaction and performance: The Case Of South Carolina State University School Of Business. College Student Journal,37(2):298- 11.

[13] Keith S. T (2017). The Use of Cronbach's Alpha When Developing and Reporting Research Instruments in Science Education. Science Education Centre, Faculty of Education, University of Cambridge, 1273-1296.

[14] Nolen, S. B. (2003). Learning environment, motivation, and achievement in high school science. Journal of Research in Science Teaching, 40(4), 347-368.

[15] Onwuegbuzie, A. J. (1997), Writing a Research Proposal: The Role of Library Anxiety, Statistics Anxiety, and Composition Anxiety, Library \& Information Science Research, Vol. 19, 5-33.

[16] Raychaudhuri, A, Debnath, M, S \& Majundra, G. (2010). Factors affecting Student's academic performance: A case study in agartala municipal council area. Bangladesh e-journal of sociology, vol.7, Number.2.

[17] Schau, C. (2003), Survey of Attitudes Toward Statistics (SATS-36). [Online: http://evaluationandstatistics.com/]

[18] Slameto. (2010). Belajar dan Faktor-Faktor yang Mempengaruhinya. Jakarta: Rineka Cipta.

[19] Tamimi, A. (2012). The weakness in the Academic Performance of Students. Baghdad University, College of Education, Ibn Rushd.

[20] Tamaoka, K., Ninomiya, A., \& Nakaya, A. (2003). What Makes International Students Satisfied with a Japanese University? Asia Pacific Education Review, 4(2), 119-128. 